\title{
WHEN THE LIGHTER "FADES AWAY,"* WHO PAYS? A PROBLEM IN THE DISTRIBUTION OF MARITIME RISK $\dagger$
}

THE terms of bills of lading given for shipment of goods by sea between ports of the United States and foreign ports are governed by two statutes: the Carriage of Goods by Sea Act (COGSA), ${ }^{1}$ which applies during the period while the goods are on the ocean-going vessel (from tackle to tackle) ; and the Harter Act, ${ }^{3}$ which, except while the goods are aboard the vessel, governs the entire period of carrier custody of the goods-a period defined as ending once a "proper delivery" has been made. ${ }^{4}$ Carriers, probably seeking the benefit of COGSA's positive exculpation for all but negligently caused damages, frequently use uniform bills which stipulate that COGSA shall apply throughout their entire custody of the goods, including the period governed by Harter. ${ }^{5}$ In addition, carriers attempt to prevent completely Harter's application by stipulating that "proper delivery" will occur as soon as the goods are released from the ship's tackles. ${ }^{6}$ And they more specifically seek to exculpate themselves from liability for damage during lighterage, ${ }^{7}$ even when no notice of the lighterage arrangements is given the shipper and, in fact, the lighterage is entirely under carrier control. ${ }^{8}$

The validity of contractual allocations of these delivery risks to the shipper has been questioned, most recently in Caterpillar Overseas, S.A. v. S.S. Ex-

*When a lighter sinks in calm sea without apparent reason, she is said, in the picturesque phrase of the waterfront, to have faded away. The Jugshoved, $290 \mathrm{Fed} .733,735$ (1923).

†Caterpillar Overseas, S.A. v. S.S. Expeditor, 210 F. Supp. 478 (S.D.N.Y. 1962), revid, 318 F.2d 720 (2d Cir.), cert. denied, 84 Sup. Ct. 347 (1963).

1. 49 Stat. 1207-13 (1936), 46 U.S.C. $\$ \S 1300-13$ (1958) (hereinafter referred to as "COGSA" with section number).

2. COGSA § 7 .

3. 27 Stat. $445-46$ (1893), 46 U.S.C. $\$ \S 190-96$ (1958) (hereinafter referred to as "Harter" with section number).

4. Harter $\$ 1$.

5. See, e.g., Isthmian S.S. Co. v. California Spray-Chem. Corp., 290 F.2d (1961), aff'd on rehearing, 300 F.2d 41 (9th Cir. 1962); Mackey v. United States (The Yoro), 83 F. Supp. 14 (S.D.N.Y. 1948), aff'd, 197 F.2d 241 (2d Cir. 1952).

6. This is attempted variously by clauses purporting to excuse negligence in lighterage [see, e.g., The Portuguese Prince, 209 Fed. 995 (S.D.N.Y. 1913)] or, more recently, by direct stipulation [see, e.g., Federal Ins. Co. v. American Export Lines, 113 F. Supp. 540 (S.D.N.Y. 1953)].

7. "Lighterage," as used here, refers to the transportation of goods by small craft from an ocean-going vessel to the wharf in a port where the shallowness of the harbor forbids docking by the vessels themselves.

8. Such clauses are found in almost all ocean bills of lading and are generally construed to excuse the carrier only when he has not been negligent. See, e.g., The Ogeechee, 248 Fed. 803 (E.D. Pa. 1918) ; North Amer. Smelting Co. v. Moller S.S. Co., 204 F.2d 384 (3d Cir. 1953). But cf. Isthmian S.S. Co. v. California Spray-Chem. Corp., 290 F.2d 486 (1961), aff'd on rehearing, 300 F.2d 41 (9th Cir. 1962). 
peditor. ${ }^{9}$ The American Export Lines' S.S. Expeditor had taken on two tractors consigned by the shipper, Caterpillar Overseas, for delivery in Tripoli. Because of the shallowness of the harbor, the Expeditor was required to unload onto a lighter, which American Export had hired without notice to either the shipper or consignee. After the tractors had been chocked in place on the lighter, it careened. The tractors slid into the water, and suffered severe damage. Caterpillar sued American Export in the District Court for the Southern District of New York. Clauses in the bill of lading incorporated all the carrierfavored stipulations concerning the period during which COGSA would apply and when proper delivery would be held to occur. ${ }^{10}$ The District Court found that the stipulation that delivery take place when the goods were discharged from the ship was effective to render the delivery to the lighter a proper delivery, so that Harter no longer applied. American Export was, under this view, contractually exonerated, even if it had been negligent. ${ }^{11}$ The Second Circuit, which reversed, voided the stipulations for proper delivery and lighterage responsibility, but applied without discussion, under the stipulation for COGSA, section $4(2)(q)$ of that act, which renders the carrier liable only for negligence. ${ }^{12}$ The carrier was held liable, under this stipulated provision, for its failure to sustain the burden of showing that it had exercised due diligence to provide a seaworthy lighter. ${ }^{13}$ This decision raises interesting problems of the permissible scope of contract initiative available to carriers and shippers operating under COGSA and Harter.

Under the common law, the carrier was absolutely liable, until proper delivery was made, for all damage to goods consigned to his care unless the damage was due to a rather limited group of causes generally known as force majeure and the carrier took proper precautions to avoid such damage. ${ }^{14}$ "Proper delivery" was usually effected by delivery to a fit wharf. ${ }^{15}$ To lessen their liability, carriers began to place exculpatory clauses in bills of lading, sometimes to relieve themselves of strict liability but often purporting to excuse even negligence. By late in the nineteenth century, such clauses had be-

9. 210 F. Supp. 478 (S.D.N.Y. 1962), rev'd, 318 F.2d 720 (2d Cir.), cert. denicd, 84 Sup. Ct. 347 (1963). The statement of facts is based on the Court of Appeals' opinion.

10. See Clauses 1, 4 and 12, American Export Lines, Inc. Standard Bill of Lading, Appendix to Brief for Respondent, Caterpillar Overseas, S.A. v. S.S. Expeditor, 318 F.2d 720 (2d Cir. 1963) (hereinafter referred to as "American Export Bill of Lading").

11. 210 F. Supp. at 480.

12. 318 F.2d at 724 .

13. The Court of Appeals found that the careening of the lighter in a calm sea raised a presumption of unseaworthiness, citing Commercial Molasses Corp. v. New York Tank Barge Corp., 314 U.S. 107, 111-12 (1941). 318 F.2d at 725. It also held that the carrier was unable to demonstrate due diligence in attempting to provide a seaworthy lighter and, impliedly, that any finding to the contrary would be "clearly erroneous" and hence could be reversed, implicitly relying upon McAllister v. United States, 348 U.S. 19, 20-21 (1954). 318 F.2d at 725.

14. The Propeller Niagara v. Cordes, 62 U.S. (21 How.) 7, 23 (1858).

15. See The Eddy, 72 U.S. (5 Wall.) 481, 495 (1866). There were other means of making proper delivery, but they were generally functional equivalents of wharf delivery. 
come standard components of contracts for the carriage of goods by sea. ${ }^{16}$ In Liverpool \& Great Western S.S. Co. v. Phenix Ins. Co., ${ }^{17}$ decided in 1889, the Supreme Court found shippers unable to "higgle or stand out" when carriers proposed bills of lading containing exculpatory language; it held that the shippers would be afforded protection by the judiciary; no maritime common carrier would be allowed to exculpate himself from the consequences of his own negligence or that of his servants. ${ }^{18}$

In 1893, Congress passed the Harter Act, which enacted in statutory form most of the doctrine enunciated in Liverpool \& Great Western, and rested upon the same theory of adhesion in carrier-shipper contracts. ${ }^{19}$ With one exception, ${ }^{20}$ Harter does not enact positive law, but states only that the carrier may not exculpate itself from certain risks in its bill of lading. ${ }^{21}$ Thus, the carrier cannot enforce any contract clause relieving him of the obligations to use due diligence to furnish a seaworthy vessel, including a proper master and crew, and to exercise proper care in loading, stowing, preserving, and delivering the cargo.22 On the other hand, the statute does not apply to clauses that exculpate the carrier from his common-law liability for damage not caused by negligence, ${ }^{23}$ and such clauses are almost invariably included in modern bills.

16. See Green, The Harter Act, 16 HARv. L. Rev. 157, 159 (1903).

17. 129 U.S. 397 (1889).

18. Id. at 439-41.

19. See The Delaware, 161 U.S. 459 (1896) ; Koppers Conn. Coke Co. v. James McWilliams Blue Line, Inc., 89 F.2d 865, 866 (2d Cir. 1937); The Willdomino, 300 Fed. 5 (3d Cir. 1924) ; Tan Hi v. United States, 94 F. Supp. 432, 434 (N.D. Cal. 1950); Green, The Harter Act, 16 HaRv. L. Rev. 157, 159 (1903); other evidence of this anticarrier spirit may be found in the policy of construing the terms of the Act strictly against the carrier. See The Newport, 7 F.2d 452, 454 (9th Cir. 1925). See also May v. Hamburg-Amerikanische Packetfahrt Aktiengesellschaft (The Isis), 290 U.S. 333 (1933); Smith v. Booth, 122 Fed. 626, 628 (2d Cir. 1903) ; Comment, 27 VA. L. Rev. 1078, 1080 (1941) ; Note, 34 Colum. L. Rev. 357 (1934).

The act was not, however, a clear victory for shippers, but a compromise between the responsibilities urged by shippers and embodied in the Liverpool \& Great Western doctrine and the less stringent requirements urged by carriers. See Green, The Harter Act, 16 HARv. L. REv. 157, 159 (1903).

20. If due diligence to make the vessel seaworthy has been exercised, the carrier will not be liable for damage to goods due to errors in navigation. Harter $\S 3$. This exception is probably based on the theory that the carrier's primary interest in the ship is sufficient to induce him to give strictest orders regarding navigation and thus excuse him from any complicity in such situations.

21. This approach results in lengthy and technical bills of lading because carriers attempt to relieve themselves of liability for all the various types of damage not caused by their fault for which such relief is permissible.

22. Harter $\$ \S 1 \& 2$.

23. This is the necessary implication from Harter's voiding only clauses exculpating from negligence. 
COGSA, passed in 1936 and based upon a uniform act drafted by the Hague Convention of $1924,{ }^{24}$ has much the same rationale as Harter and Liz'erpool $\mathcal{E}$ Great Western, but is largely drafted in positive terms. ${ }^{25}$ The parties' relations are clearly fixed by the statute, no contractual stipulation being necessary to abrogate the common law strict liability ${ }^{26}$ during the tackle-to-tackle portion of sea-voyages to which it applies. ${ }^{27}$ Thus, during this time, the carrier is always liable for the consequences of his negligence (except in navigation) and never liable for non-negligent damage or damage due to errors in navigation. ${ }^{28}$ COGSA specifically leaves Harter in effect during the pre- and posttackle periods. ${ }^{29}$

Since the accident in Caterpillar took place after the goods had left the ship's tackles, the affirmative terms of COGSA no longer applied of their own force. $^{30}$ Within the limits set by Harter, the parties were free to structure their responsibilities. One clause in the American Export bill sought to prevent entirely Harter's application after the goods had left the ship, by defining discharge as complete delivery. ${ }^{31}$ Were this clause effective to define "proper delivery" under Harter, the carrier could transfer to the shipper all risk of subsequent damage. ${ }^{32}$

The Second Circuit's negative response to this term of the contract was grounded in an appreciation of the adhesionary relationship between shippers and carriers which had led Congress to enact Harter originally. ${ }^{33}$ To allow carriers to define the time at which "proper delivery" occurred would be to deprive shippers of the protection Congress intended them to have under the

24. See Comment, 27 VA. L. Rev. 1078 (1941).

25. See Gilmore \& Black, The Law of Admiralty 123-24 (1957) ; Comment, 27 VA. L. REV. 1078 (1941).

26. See COGSA $\S 4(2)(q)$.

27. COGSA $\$ 7$.

28. See COGSA $\S \S 3$ \& 4. See generally GILMoRE \& BLACK, op. cit. supra note 25, ch. 3; Knauth, The American Law of Ocean Bills of Ladrng 163-71 (1953); Comment, 27 VA. L. Rev. 1078 (1941); Note, 23 VA. L. Rev. 590 (1937).

29. COGSA \& 12 .

30. COGSA \& 7. A contrary argument, when goods are still being loaded onto the lighter, has been sustained when interpreting the British COGSA, Goodwin Ferreira \& Co. v. Lamport \& Holt, Ltd., 34 Lloyd's List L.R. 192 (1929), and has been given some credence in American courts, Hoegh Lines v. Green Truck Sales, Inc., 298 F.2d 240 (1962), reversing, 179 F. Supp. 562 (S.D. Cal. 1960) ; Remington Rand Co. v. American Export Lines, 132 F. Supp. 129 (S.D.N.Y. 1955). But the construction has not generally found favor in American courts. Federal Ins. Co. v. American Export Lines, 113 F. Supp. 540 (S.D.N.Y. 1953); Note, 23 Modern L. Rev. 564 (1960). The court specifically declined to rule on this point in Caterpillar, saying, correctly in view of its disposition of the contractual clauses under Harter, that it made no difference which Act applied.

31. American Export Bill of Lading, Clause 4.

32. After proper delivery the carrier owes no positive duties to the goods, so that he would have no duty to provide a seaworthy lighter. See, e.g., North Amer. Smelting Co. v. Moller S.S. Co., 204 F.2d 384 (3d Cir. 1953).

33. See note 19 supra. 
Harter Act just because carriers could force such exculpatory clauses upon them. If those protections were to be meaningful, carriers could not define in their contracts the jurisdictional terms upon which application of the act depended. ${ }^{34}$

In the context of judicial development of "proper delivery" under the common law and Harter, the Second Circuit was correct in finding that proper delivery had not occurred. Under established doctrine, proper delivery could be made by delivering the goods into the possession of the consignee or by placing the cargo on a fit wharf in the port of destination, separating the goods from the goods of other shippers, and notifying the consignee. ${ }^{35}$ These rules and the common exceptions to them-for example, that delivery to customs officials, where required, will suffice ${ }^{36}$ - seem rooted in a common rationale

34. See, e.g., Isthmian S.S. Co. v. California Spray-Chem. Corp., 290 F.2d 486 (1961), aff'd on rehearing, 300 F.2d 41 (9th Cir. 1962). The Ninth Circuit, while advancing substantially the same argument as the Second Circuit in Caterpillar, relied also on the concept that when carriage to a port is contracted, delivery to lighters in the harbor cannot discharge the entire obligation. 300 F.2d at 45. Globe Distributing Co. v. S.S. Monte Iciar, 1948 Am. Mar. Cas. 615 (3d Cir. 1948) ; Morris v. Lamport \& Holt, Ltd., 54 F.2d 925 (S.D.N.Y. 1931), aff'd per curiam, 57 F.2d 1081 (2d Cir. 1932). But cf. The Portuguese Prince, 209 Fed. 995 (S.D.N.Y. 1913) ; John Bonura \& Co. v. United Fruit Co., 162 La. 53, 110 So. 86 (1926) ; Federal Ins. Co. v. American Export Lines, 113 F. Supp. 540 (S.D.N.Y. 1953), where American Export's clause 4 was found to terminate the contractual relationship between the parties and consequently to foreclose the application of that part of the stipulation for COGSA pertaining to the statute of limitations. This resulted in carrier liability under the general maritime law, with its longer statute of limitations.

35. See, e.g., The Eddy, 72 U.S. (5 Wa11.) 481, 495 (1866) (the leading case); North Amer. Smelting Co. v. Moller S.S. Co., 204 F.2d 384 (3d Cir. 1953); Baltimore \& Ohio R.R. v. United States, 201 F.2d 795, 797 n.3 (3d Cir. 1953); The Italia, 187 F. 113 (2d Cir. 1911).

36. Tan Hi v. United States, 94 F. Supp. 432, 435 (N.D. Cal. 1950); The Milwaukee Bridge, 15 F.2d 249, 250 (S.D.N.Y. 1926). This exception grows out of the more general exception that delivery may always be made in accordance with port custom or regulation. See, e.g., The Tangier, 64 U.S. (23 How.) 28, 38-39 (1859) ; Constable v. National S.S. Co., 154 U.S. 51, 63 (1894). It might have been argued that, since lighterage was customary in the port of Tripoli, delivery had been completed when the goods were placed on the lighter. But even The Tangier, supra, does not appear to stand for that result. And any doubt in that regard should be laid to rest by Bulkley v. Naumkeag Steam Cotton Co., 65 U.S. (24 How.) 386, 391 (1860), where the Court recognized the exception propounded in The Tangier but held the carrier liable when a lighter hired by him in accordance with port custom blew up while transporting goods to the ship. The argument is further contradicted by the many cases where carriers have been held liable for damage during lighterage, for lighterage is undertaken almost exclusively where it is the custom of the port. See, e.g., Isthmian S.S. Co. v. California Spray-Chem. Corp., 290 F.2d 486 (1961), aff'd on rehearing, 300 F.2d 41 (9th Cir. 1962); Colton v. New York \& Cuba Mail S.S. Co., 27 F.2d 671 (2d Cir. 1928); The Ogeechee, 248 Fed. 803 (E.D. Pa. 1918).

The doctrine that the carrier may terminate his carrier liability when the goods are discharged from the vessel may also appear to furnish an exception to the rule of responsibility until the goods are placed on a wharf. But this means only that the carrier 
of control. Where it is the carrier or his agents who have physical control of the goods, the doctrine of proper delivery works to place responsibility on the carrier, as the party best able to avoid negligent damage to the goods. ${ }^{37} \mathrm{Al}$ location of risk to the party best able to avoid its fruition is in general the distribution sought by Harter and COGSA, and the result accomplished by Caterpillar. 38

Since the Harter Act was held to apply to the situation involved, court interest focused on a second contract stipulation : a term attempting to structure the distribution of risks of lighterage by a specific clause placing "all lighterage and use of craft in discharging ... at the risk and expense of the [shipper]."39 Because of lower court findings in Caterpillar, the clause was viewed as exculpating the carrier from all liability, even for negligence; consequently, the Court of Appeals found it plainly prohibited by Harter. ${ }^{40}$ Normally, however, such stipulations have been upheld, on the ground that they may terminate his common-law absolute liability upon discharge from the ship. See Krauth, op. cit. supra note 28, at 145; Poor, American Law of Charter Parties and Buls of Lading 140 (4th ed. 1954). See also Smith v. Britain S.S. Co., 123 Fed. 176 (S.D.N.Y. 1903) ; Insurance Co. of N. Amer. v. North German Lloyd Co., 106 Fed. 973 (D. Md. 1900).

37. The doctrines of permissible proper delivery to a wharf, to the consignee or his agents, or to customs officials are all consistent with this rationale and the cases estatlishing and applying these doctrines bear out the underlying concept of control. See, e.g., Isthmian S.S. Co. v. California Spray-Chem. Corp., 290 F.2d 486 (1961), aff'd on rehearing, 300 F.2d 41 (9th Cir. 1962) (see note 34 supra); North Amer. Smelting Co. v. Moller S.S. Co., 204 F.2d 384 (3d Cir. 1953) (carrier had fulfilled duty while goods were in his control; damage occurred afterward); Globe Distributing Co. v. S.S. Monte Iciar, 1948 Am. Mar. Cas. 615 (3d Cir. 1948) (carrier, liable, had effective control although damage might have occurred after the goods were on the wharf); Colton v. New York \& Cuba Mail S.S. Co., 27 F.2d 671 (2d Cir. 1928) (carrier liable in transshipment lighterage) ; Vitelli v. Cunard S.S. Co., 203 Fed. 697 (2d Cir. 1913) (carrier responsible for goods discharged onto open pier); Smith v. Booth, 122 Fed. 626 (2d Cir. 1903) (transshipment); The Ogeechee, 248 Fed. 803 (E.D. Pa. 1918) (lighter hired by carrier); Insurance Co. of N. Amer. v. North German Lloyd Co., 106 Fed. 973 (D. MId. 1900) (lighter hired by carrier). The contrary may be implied from, but is not a necessary result of, language in Federal Ins. Co. v. American Export Lines, 113 F. Supp. 540 (S.D.N.Y. 1953); The Portuguese Prince, 209 Fed. 995 (S.D.N.Y. 1913) ; John Bonura \& Co. v. United Fruit Co., 162 La. 53, 110 So. 86 (1926).

Control is even more obviously the crucial factor in cases where damage occurred before the goods had reached the ship. See, e.g., Bulkley v. Naumkeag Steam Cotton Co., 65 U.S. (24 How.) 386 (1860) ; Mackey v. United States (The Yoro), 83 F. Supp. 14 (S.D.N.Y. 1948), aff'd, 197 F.2d 241 (2d Cir. 1952); Palmer v. Agwilines, Inc., 135 F.2d 689 (2d Cir. 1943) ; Morris v. Lamport \& Holt, Ltd., 54 F.2d 925 (S.D.N.Y. 1931), aff'd mem., 57 F.2d 1081 (2d Cir. 1932).

38. See notes $19 \& 20$ supra and accompanying text.

39. American Export Bill of Lading, clause 12.

40. The District Court and both parties appear to have assumed that the clause would exculpate from negligence and the Second Circuit consequently thought the question foreclosed. 
do not exculpate for negligence and hence are not prohibited by Harter. ${ }^{41}$ Under the common law and Harter such stipulations are said to shift the burden of proof of carrier negligence to the shipper as well as to exonerate the carrier for non-negligent damage. ${ }^{42}$

The final relevant stipulation in the contract-one honored without discussion by the Second Circuit-stated that COGSA should govern throughout the contractual period, where not inconsistent with specific stipulations. ${ }^{43}$ Such stipulations for the application of COGSA, while not much before the courts, appear to be increasingly common, for they offer parties a desirable uniformity of applicable law during the contractual period. ${ }^{44}$ One obvious limitation to the effect of such stipulations is that they may apply only through Harter. They can neither abrogate nor condition Harter's application to the post- or pre-tackle period, nor validly introduce a condition forbidden by Harter to bills of lading. ${ }^{45}$ Thus, COGSA's limitation of application to the tackle-totackle period must be read as not intended or applicable as part of the stipulated statutory material. On the other hand, all but one of the substantive provisions of COGSA ${ }^{46}$ provide for carrier liability in the event of negligence,

41. This construction does not appear to accord with the natural meaning of the clause but the overwhelming weight of precedent supports it. See, e.g., Bulkley v. Naumkeag Steam Cotton Co., 65 U.S. (24 How.) 386 (1860) ; North Amer. Smelting Co. v. Moller S.S. Co., 204 F.2d 384 (3d Cir. 1953) ; Morris v. Lamport \& Holt, Ltd., 54 F.2d 925 (S.D.N.Y. 1931), aff'd mem., 57 F.2d 1081 (2d Cir. 1932). But see Isthmian S.S. Co. v. California Spray-Chem. Corp., 290 F.2d 486 (1961), aff'd on rehearing, 300 F.2d 41 (9th Cir. 1962).

42. The shipper has the initial burden of showing damage while the goods were in the carrier's custody but such a showing is sufficient to render the carrier liable unless he brings forward a permissible exculpatory clause which applies to the situation. This will place the burden of showing negligence on the shipper. If the shipper proves that part of the damage was occasioned by negligence, the carrier will be liable for all of the damage unless he can demonstrate what part of the loss was not due to his negligence. See, c.g., Schnell v. The Vallescura, 293 U.S. 296 (1934); Clark v. Barnwell, 53 U.S. (12 How.) 272 (1851) ; The Ponce, 67 F. Supp. 725, 727 (D.N.J. 1946), aff'd per curiam, 160 F.2d 107 (3d Cir. 1947); Copco Steel \& Eng'r Co. v. S.S. Alwaki, 131 F. Supp. 332 (S.D.N.Y. 1955). But see Globe Distrib. Co. v. S.S. Monte Iciar, 1948 Am. Mar. Cas. 615, 620 (3d Cir. 1948) (O'Connell, J., dissenting).

43. American Export Bill of Lading, clause 1.

44. See note 48 infra. And see, e.g., Remington-Rand, Inc. v. American Export Lines, Inc., 132 F. Supp. 129 (S.D.N.Y. 1955) ; Federal Ins. Co. v. American Export Lines, Inc., 113 F. Supp. 540 (S.D.N.Y. 1953).

45. See COGSA $\$ 12$; KNAUtH, op. cit. supra note 28 , at 167-68.

46. COGSA $\S 4(2)$ (a) provides that the carrier shall not be liable for damage due to negligence in navigation. Harter $\$ 3$, however, exculpates the carrier for negligence in navigation only when due diligence to make the vessel seaworthy has been undertaken. See May v. Hamburg-Amerikanische Packetfahrt Aktiengesellschaft (The Isis), 290 U.S. 333 (1933), which thus construed Harter $\$ 3$ and, it is said [KNAUTr, op. cit. supra note 28, at 167; Comment, 27 VA. L. REv. 1078 (1941)], speeded the passage of COGSA. See also Note, 47 HARv. L. Rev. 715 (1934). In a case where damage was due to negligence in navigation and due diligence to provide a seaworthy vessel had not been 
and so would be readily permissible as stipulations under Harter; the exception is not important, and ought not affect the overall validity of the stipulation. ${ }^{\mathbf{4 7}}$ Rather, the stipulation can be interpreted as a shorthand manner of stipulating COGSA's individual clauses. ${ }^{48}$ This, in fact, was the interpretation the Second Circuit seemed to place upon the contract, in finding that the parties had effectively stipulated for COGSA's section 4(2) (q).

Complications would arise if a contract containing a lighterage clause interpreted to exculpate only for non-negligence also contained a stipulation, as in Caterpillar, that COGSA apply throughout the carrier's custody of the goods. COGSA's burden of proof is one of the components of that act which can be stipulated in place of Harter. There are differences between the two burdens-under Harter an exculpatory clause normally shifts the burden of showing negligence to the shipper ${ }^{49}$ while COGSA $4(2)$ (q) would place the burden of showing non-negligence on the carrier. ${ }^{50}$ Of course, being more favorable to the shipper, the COGSA burden is a permissible stipulation under Harter. ${ }^{51}$ But the question of which applies is far from academic. These two clauses often appear together, ${ }^{52}$ and the burden of proof is often conclusive ${ }^{53}$ because of the shipper's difficulty in bringing evidence of negligence while the goods are in the carrier's custody. The problem is further complicated by the fact that COGSA is often stipulated "except as . . . otherwise provided."

Since the court held the lighterage clause void in Caterpillar, it did not reach the question whether placement of the burden on the shipper was "otherwise specifically provided." Some aid in resolving the question is given by a footnote in which the court intimated that properly drafted clauses would have shifted the burden to the shipper. ${ }^{55}$ Where there is no mention of the burden of proof, however, it is doubtful that such a clause is present. In answering questions of the extent to which the carrier is exculpated, the

undertaken, the stipulation for COGSA could exculpate for negligently caused damage. It would thus be void and impossible of application to this limited situation.

47. GIIMORE \& BLACK, op. cit. supra note 25, at 127; KNAUTH, op. cit. supra note 28, at 167. Cf. Mackey v. United States, 83 F. Supp. 14, 19 (S.D.N.Y. 1948), aff'd, 197 F.2d 241 (2d Cir. 1952) (COGSA applied without question where stipulated) ; Isthmian S.S. Co. v. California Spray-Chem. Corp., 290 F.2d 486, 493 (1961), aff'd on rehearing, 300 F.2d 41, 49 (9th Cir. 1962) (Pope, J., concurring).

48. But cf. Federal Ins. Co. v. American Export Lines, Inc., 113 F. Supp. 540 (S.D. N.Y. 1953) (finding the stipulation for COGSA a general clause controlled by other clauses considered specific).

49. See note 42 supra and accompanying text.

50. See, e.g., Schroeder Bros. v. The Saturnia, 226 F.2d 147, 149 (2d Cir. 1955); George F. Pettinos, Inc. v. American Export Lines, Inc., 68 F. Supp. 759, 761 (E.D. Pa. 1946), aff'd per curiam, 159 F.2d 247 (3d Cir. 1947).

51. See Harter $\S 1$. It is not possible that a stipulation which favors the shipper could exculpate the carrier for negligence.

52. See notes 44 and 48 supra.

53. See Schnell v. The Vallescura, 293 U.S. 296, 306 (1934).

54. See note 44 supra.

55. $318 \mathrm{~F} .2 \mathrm{~d}$ at $720,724$. 
policy of strict construction against carriers ${ }^{56}$ should be effectuated. Carrier stipulations which shift the burden of proof to the shipper themselves act as exculpatory clauses. ${ }^{57}$ Thus, as long as proper delivery has not been madeand the goods remain in the predominant control of the carrier-it seems more reasonable to place the cautionary effect of the burden on the carrier. If carriers may be expected to dominate the bargaining process no matter what statutory structure is adopted (at least in the detail of risk allocation), it would appear that COGSA's positive law approach is preferable to Harter's permissive one. ${ }^{58}$ The problem is not one of contractual intent, but of who should be primarily responsible for insurance-what system will operate best to protect the goods. COGSA is a far more precise formulation of privileges and immunities. It not only simplifies modern bills of lading, much of which are occupied with allocating the responsibilities of the parties before and after the carriage by sea, but also applies more consistently the principle that carriers should be liable for the consequences of their negligence while the goods are within their control. ${ }^{59}$

While the principle suggested has been developed in the realm of contract interpretation, it must be recognized that it goes much deeper. There is no sound reason of policy for applying two acts to different portions of a continuous carriage arrangement. ${ }^{60}$ By their stipulations for COGSA, carriers seem to have recognized and sought the benefits of uniformity. The only plausible explanation why COGSA was limited to the tackle-to-tackle situation as enacted, is that it was drafted chiefly by nations which had no equivalent to the Harter Act. ${ }^{61}$ The tackle-to-tackle period is the period during which the carrier is most obviously in control of the goods and, therefore, the period on which international agreement would be most readily reached; Congress apparently did not foresee the problems which would result under American law from the conjuncture of Harter and COGSA.

Although courts will be able to resolve many problems of contract interpretation in the post-tackle period by proceeding from the always applicable provisions of the Harter Act, they will be unable to achieve the uniformity the parties seem to desire. ${ }^{62}$ To reach this end, COGSA should be amended

56. See note 19 supra.

57. See Globe Distrib. Corp. v. S.S. Monte Iciar, 1948 Am. Mar. Cas. 615, 620 (3d Cir. 1948) (O'Connell, J., dissenting). Judge O'Connell reasoned that since shifting the burden of proof to the shipper might prevent a finding of negligence, where there had in fact been negligence, any clause which thus shifted the burden should be void under $\S 1$ of Harter.

58. See KNAUTH, op. cit. supra note 28 , at 167.

59. See notes 19 and 37 supra and accompanying text.

60. See KNaUtH, op. cit. supra note 28 , at 167-68.

61. Ibid.

62. While the courts might be able to overcome the complex problems of superimposed statutes and conflicting stipulations and thus achieve a type of uniformity, the need here is for less rather than more contractual freedoms. This is implicit in the more positive terms of the more recent statute, COGSA, which structures carrier responsibility in a more uniform and salutary manner. 
to apply throughout the period of carrier control over goods being transported by sea in foreign commerce-from the time the goods come into the control of the carrier or his agent until proper delivery has been made. The control basis of the proper delivery requirement should be explicitly recognized to make it clear that that requirement seeks to allocate risk to the party best able to avoid its fruition by his choice, inspection, or care. The primary bencfit of the revision would be to impose uniform responsibilities on the carrier during the entire time that the goods are in his control. 